\title{
The Eleonore Sø and Målebjerg foreland windows, East Greenland Caledonides, and the demise of the 'stockwerke' concept
}

\author{
A.K. Higgins and A. Graham Leslie
}

Recognition of the Eleonore Sø and Målebjerg foreland windows during the 1997-1998 regional mapping expeditions to the East Greenland Caledonides provided critical evidence for largescale, westward-directed thrusting in the Kong Oscar Fjord region $\left(72^{\circ}-75^{\circ} \mathrm{N}\right)$, a revelation that dealt a final blow to the 'stockwerke' concept of an in situ highly mobile infrastructure characterised by rising fronts of Caledonian migmatisation and metasomatism. This paper reviews earlier investigations in both the Eleonore $\$ \varnothing$ and Målebjerg areas, and the misinterpretations of rock units that initially obscured recognition of their foreland affinity. The Eleonore $S \varnothing$ and Målebjerg windows can now be placed in context, as part of the lowest structural level of the foreland-propagating thrust pile of the Kong Oscar Fjord region.

Keywords: Caledonides, East Greenland, tectonic windows

A.K.H., Geological Survey of Denmark and Greenland, Øster Voldgade 10, DK-1350 Copenhagen K, Denmark. Email:akh@geus.dk

A.G.L., British Geological Survey, Murchison House, Edinburgh EH9 3LA, UK.

The $1300 \mathrm{~km}$ long East Greenland Caledonides ( $70^{\circ}-$ $\left.81^{\circ} 30^{\prime} \mathrm{N}\right)$ can be broadly divided into western marginal and eastern thick-skinned thrust belts (Fig. 1; Higgins \& Leslie 2000; Higgins et al. 2001, 2004). The western thrust margin of the orogen against the Caledonian foreland is largely obscured by the Greenland Inland Ice, with the most continuous foreland exposures west of Kronprins Christian Land in the extreme north. Elsewhere foreland areas are locally preserved in the westernmost nunataks and in scattered tectonic windows exposed along the length of the marginal thrust belt (Fig. 1). While the foreland windows all exhibit some disturbance due to Caledonian deformation, and have therefore been classified as parautochthonous, the similarities of the successions preserved within the various windows and that in the undisturbed foreland, suggest they are only slightly displaced from their original locations (Higgins et al. 2001). Prior to the Survey's 1997-1998 regional mapping programme, large-scale thrusting had not been demonstrated in the Kong Oscar Fjord region (Fig. 2; $\left.72^{\circ}-75^{\circ} \mathrm{N}\right)$. Indeed, new investigations in this region (Hartz \& Andresen 1995; Andresen \& Hartz 1998; Andresen et al. 1998), had led to interpretations of Caledonian orogenesis in terms of upward and lateral movement of light, low viscosity, lower crustal material towards the region of maximum crustal extension, a process compared to Haller's (1953, 1970, 1971) 'stockwerke' concept, and that carried the implication that orogenic contraction was negligible.

The recognition of the Målebjerg and Eleonore Sø foreland windows during the Survey's 1997-1998 regional mapping provided incontrovertible evidence for large-scale westward-directed Caledonian thrusting in the Kong Oscar Fjord region (Figs 2, 3). This discovery completely undermined arguments for explaining orogenic development in terms of the in situ 'stockwerke' concept or similar processes, and at the same time resolved a number of outstanding problems of East Greenland geology. The areas of both 


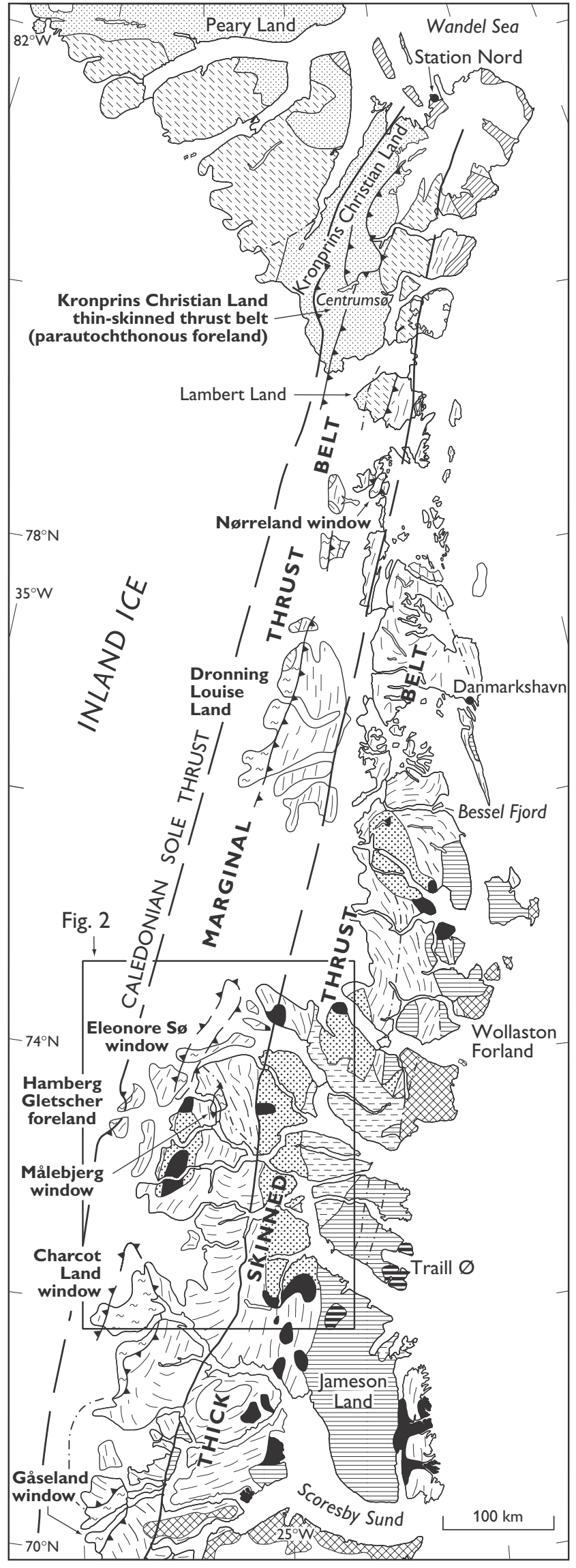

POST-CALEDONIAN

Palaeogene basalts

Palaeogene intrusions

Wandel Sea Basin:

Carboniferous-Palaeogene sediments

East Greenland basins:

Carboniferous-Cretaceous sediments

\section{LATE TO POST-CALEDONIAN}

Devonian - continental sediments

\section{CALEDONIAN OROGENIC BELT}

Late to post-kinematic granites

Neoproterozoic-Ordovician sediments (East Greenland)

Neoproterozoic-Silurian sediments

(eastern North Greenland)

Palaeo-Mesoproterozoic sediments and basalts (eastern North Greenland)

Crystalline complexes and sediments

(Archaean-Mesoproterozoic)

\section{CALEDONIAN FORELAND}

Neoproterozoic-Silurian sediments (North Greenland)

Palaeo-Mesoproterozoic sediments and basalts (eastern North Greenland)

Mainly crystalline rocks -

parautochthonous windows

$\checkmark$ Thrust

...- Fault/shear zone

Tectonic zone boundary

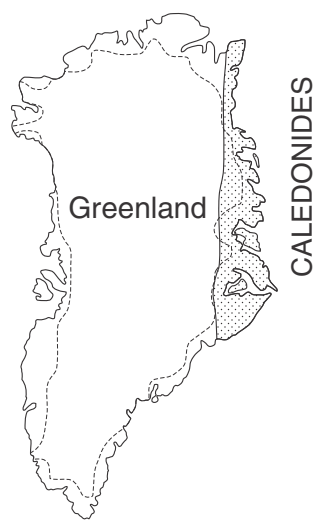

Fig. 1. Geological map of the East Greenland Caledonides, showing location of the foreland windows in the western marginal thrust belt. The frame indicates the region between $71^{\circ} 50^{\prime}$ and $74^{\circ} 30^{\prime} \mathrm{N}$, shown at a larger scale in Fig. 2, which includes the Målebjerg and Eleonore Sø windows. Modified from Higgins \& Leslie (2000). 
Fig. 2. Geological map of North-East Greenland $71^{\circ} 50^{\prime}-$ $74^{\circ} 30^{\prime} \mathrm{N}$, showing location of the

Eleonore $S \varnothing$,

Målebjerg and

Charcot Land

windows, and the Hamberg Gletscher foreland. The legend depicts the units contained in the two thrust sheets and Franz Joseph allochthon overlying the windows. The Målebjerg and Eleonore $S \varnothing$ areas are shown in more detail in Figs 5 and 6. ES, Eleonore Sø; FJD, Franz Joseph detachment; FRF, Fjord region fault; KFJF, Kejser Franz Joseph Fjord; LBL, Louise Boyd Land; M, Målebjerg; ML, J.L. Mowinckel Land; P, Petermann Bjerg; PD, Petermann detachment. The line of the cross-section shown in Fig. 3 is indicated.

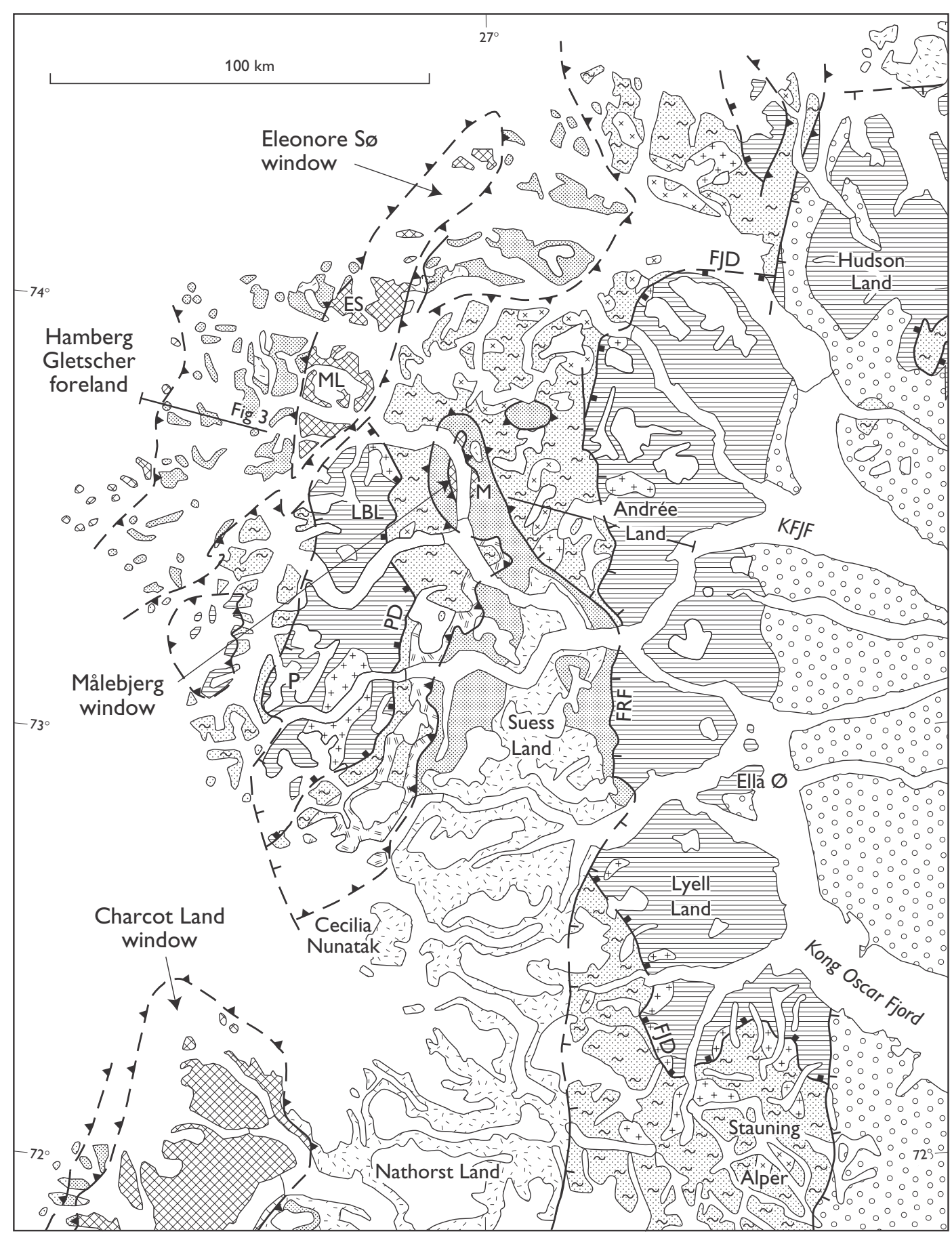

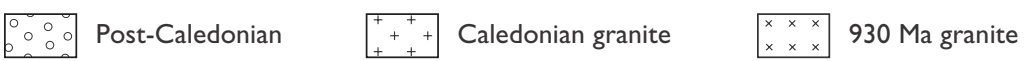

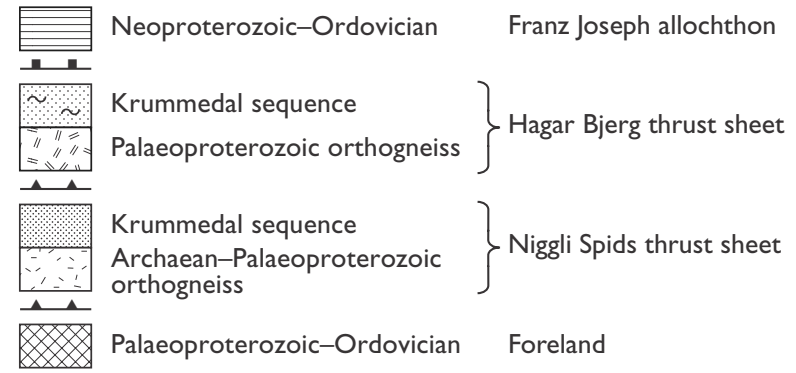


windows had been investigated prior to the Survey's regional mapping, the Eleonore $S \varnothing$ area by Katz (1952) and the Målebjerg area in Andrée Land by Haller (1953). However, while Haller (1971) had speculated that the Eleonore $S \varnothing$ region might be a window (see below), neither Katz nor Haller identified the Lower Palaeozoic rock units whose presence clarifies the structural setting beyond any doubt.

This paper reviews the history of investigations in the Eleonore Sø and Målebjerg areas, and the early misinterpretations of rock units that obscured their recognition as parts of the Caledonian foreland. These misinterpretations were closely linked to the evolution of ideas to explain orogenic developments in East Greenland, that culminated in the 'stockwerke' concept as elaborated by Haller (1970, 1971).

Haller's 'stockwerke' model was a development of the earlier ideas of Backlund (1930, 1933) and Wegmann (1935). The crystalline gneiss complexes constituting the central metamorphic complex that underlie, and appear to be interleaved with high grade metasediments, were envisaged by Haller as elements of a highly mobile infrastructure formed by the rise of Caledonian fronts of migmatisation and metasomatism. Associated mechanical and chemical changes were thought to have led to in situ transformation of a succession of sedimentary rocks into the gneissic and granitic rocks of the infrastructure, which was considered 'entirely rejuvenated'. The mobile migmatite domes of the infrastructure were bordered by and overlain by the more rigid sedimentary suprastructure, with the two levels separated by a thick, often strongly folded, 'zone of detachment'. The term 'stockwerke' refers to the different levels of the growing orogenic belt; in German 'stockwerke' refers to the floors or stories of a house. In Haller's map compilations the infrastructure of the central metamorphic complex is depicted as Caledonian synorogenic granite (Koch \& Haller 1971), and he remarks that regional thrusting was probably of "no importance in their formation" (Haller 1971, p. 179). The spectacular 'stockwerke' structures in East Greenland, and Haller's drawings, are still presented in modern textbooks (e.g. Best 2003) as classic examples of mantled gneiss domes, and metamorphic core complexes.

The Målebjerg and Eleonore $\mathrm{S} \varnothing$ windows can now be placed in their correct context as parts of the lowest structural level of the foreland-propagating thrust pile in the southern half of the Caledonian orogen $\left(70^{\circ}-75^{\circ} \mathrm{N}\right.$; Elvevold et al. 2000; Higgins et al. 2004). These foreland windows are structurally overlain by a lower Niggli Spids thrust sheet and an upper Hagar Bjerg thrust sheet, both with substantial westward displacements (Fig. 3). The very thick Neoproterozoic to Lower Palaeozoic succession (Eleonore Bay Supergroup, Tillite Group, Kong Oscar Fjord Group) is distinguished as the Franz Joseph allochthon, and viewed as an upper detached part of the Hagar Bjerg thrust sheet.

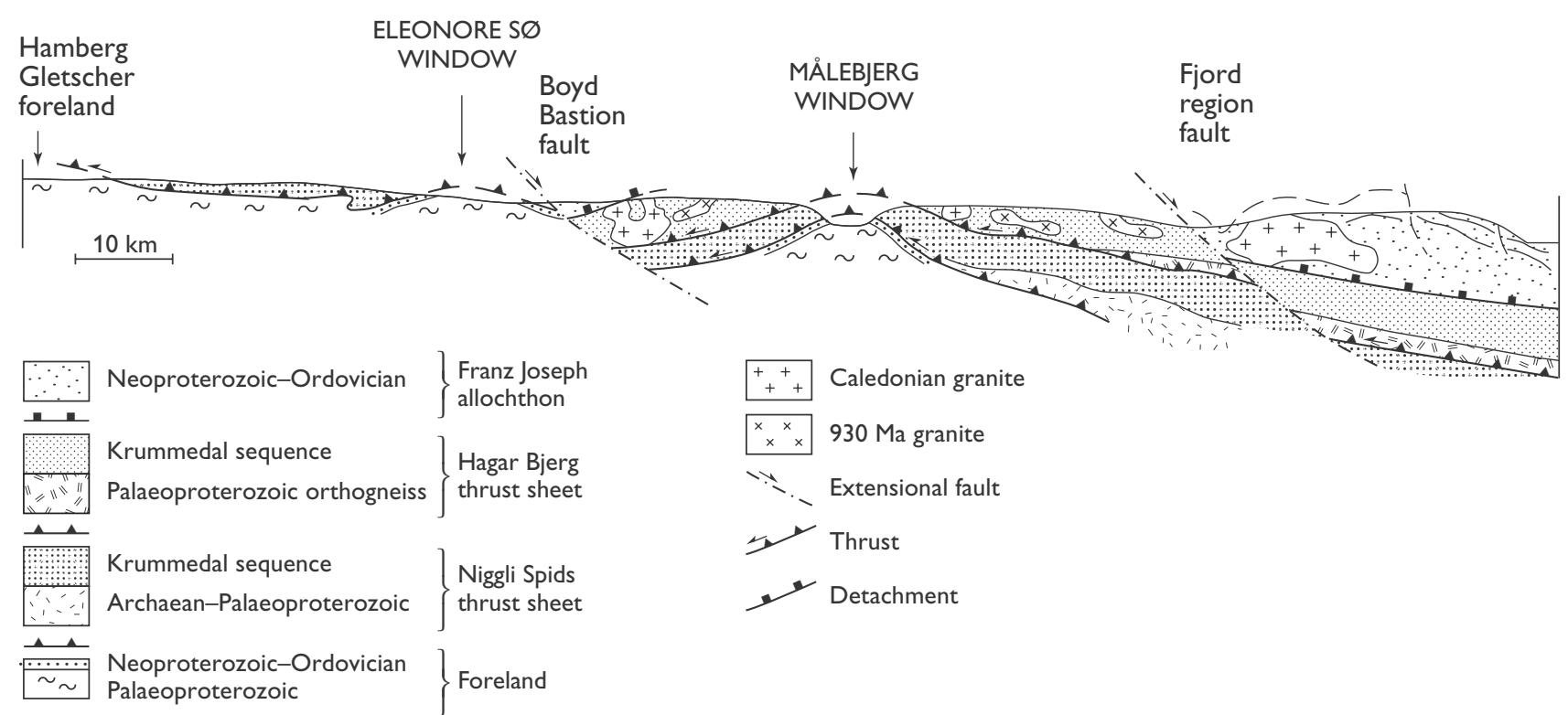

Fig. 3. Cross-section through the Eleonore $\$ \varnothing$ and Målebjerg windows showing the foreland windows overlain by two thrust sheets and the Franz Joseph allochthon. Section line is indicated on Fig. 2. 


\section{Geological setting}

The Eleonore Sø and Målebjerg windows (Figs 2, 3) are characterised by thin $(<400 \mathrm{~m})$ Neoproterozoic Lower Palaeozoic sedimentary successions. The latter comprise a lens-like $31 \mathrm{~m}$ thick diamictite in the Målebjerg window correlated with the Vendian Tillite Group, a 143-350 m thick quartzite sequence with Skolithos ichnofossils of Early Cambrian age defined as the Slottet Formation, and a $32-45 \mathrm{~m}$ thick dolomite sequence of Cambrian-Ordovician age defined as the Målebjerg Formation (Smith et al. 2004, this volume). This thin Vendian-Ordovician foreland succession is in great contrast to the $18.5 \mathrm{~km}$ thick, partly equivalent succession, preserved in the structurally overlying Franz Joseph allochthon. In the Eleonore Sø window the Slottet Formation overlies a Palaeoproterozoic sedimentary-volcanic assemblage with profound unconformity, and in the Målebjerg window unconformably overlies gneisses of presumed Palaeoproterozoic age.

The Niggli Spids thrust sheet structurally overlying both windows (Fig. 3) incorporates crystalline gneiss complexes and high-grade metasedimentary successions, which were reworked to varying degrees during Caledonian orogenesis. Ion microprobe studies on zircons from the orthogneisses have yielded Archaean and Palaeoproterozoic protolith ages (Thrane 2002; unpublished data 2004, F. Kalsbeek and A.P. Nutman), that confirm earlier less precise isotopic ages by other methods (e.g. Rex \& Gledhill 1981). The highgrade metasedimentary rocks of both the Niggli Spids thrust sheet and the higher Hagar Bjerg thrust sheets are correlated with the Krummedal supracrustal sequence (Higgins 1988). The Krummedal sequence metasedimentary rocks in the Hagar Bjerg thrust sheet host a suite of 940-910 Ma augen granites generated during an early Neoproterozoic thermal event (Kalsbeek et al. 2000; Watt et al. 2000; Watt \& Thrane 2001). Ion microprobe studies of detrital zircons from the Krummedal sequence show the youngest detrital zircons are about $1050 \mathrm{Ma}$ old, and deposition of the sediments must therefore have taken place in the period c. 1050-940 Ma ago (late Mesoproterozoic - early Neoproterozoic). High-grade regional metamorphism and associated anatexis during the Caledonian orogeny led to generation of a new suite of 440-425 Ma granites (Watt et al. 2000; Hartz et al. 2001; Kalsbeek et al. 2001a, b).

The Franz Joseph allochthon is made up of the $c$. $13 \mathrm{~km}$ thick Neoproterozoic Eleonore Bay Supergroup
(Riphean-Sturtian; post-900 to c. $590 \mathrm{Ma}$ ), the 800$1000 \mathrm{~m}$ thick Vendian Tillite Group (Hambrey \& Spencer 1987), and the c. $4 \mathrm{~km}$ thick Cambrian-Ordovician Kong Oscar Fjord Group (Cowie \& Adams 1957; Smith \& Bjerreskov 1994; Smith et al. 2004, this volume). This succession is widely exposed in the central fjord system of the Kong Oscar Fjord region, and also occurs in a more restricted area to the west in Louise Boyd Land and around Petermann Bjerg (Fig. 2). The contact between the Eleonore Bay Supergroup and underlying high-grade Krummedal metasediments of the Hagar Bjerg thrust sheet is a shear zone, in which both extensional and contractional strain have been recorded. In the west the shear zone is known as the Petermann detachment (PD, Fig. 2; Escher \& Jones 1998, 1999), and in the east the Franz Joseph detachment (FJD, Fig. 2). The latter is only well exposed between northern Andrée Land and Hudson Land (Leslie \& Higgins 1998, 1999), and between Lyell Land and the Stauning Alper (cf. Tindern detachment of White et al. 2002). In most of the fjord region the present-day west limit of the Eleonore Bay Supergroup outcrop is a late-orogenic extensional fault, the 'fjord region fault' of this paper (FRF, Fig. 2). This corresponds to the 'fjord zone fault' of Larsen \& Bengaard (1991) and to part of the 'fjord region detachment' system of Hartz \& Andresen (1995) and co-workers (Andresen et al. 1998; Hartz et al. 2000; White et al. 2002). Conodonts extracted from the uppermost levels of the Ordovician succession exhibit very low conodont alteration indices (Smith 1991; Stouge et al. 2002), which demonstrate that the Franz Joseph allochthon in this region cannot have been over-ridden by higher thrust sheets.

\section{Historical review: the Målebjerg and Eleonore Sø areas}

The investigations of John Haller and others working with Lauge Koch's long series of East Greenland geological expeditions (1926-1958) more than 40 years ago, essentially predated the era of isotopic age determinations. The first, very few, K-Ar ages from East Greenland only became available in 1961 (Haller \& Kulp 1962), after the cessation of field work in 1958. The evolution of ideas and the conclusions of their studies were thus almost entirely based on field observations and interpretations. The revolutionary concept of plate tectonics did not make its mark until the late 1960 s, and while it was widely accepted by many 
geologists, John Haller considered that its enthusiastic reception had obscured its shortcomings (see Haller 1979).

Lauge Koch's sledge journeys along the length of the Caledonian orogen led him to propose that the greater part of the gneisses that previous expeditions assumed to be Archaean were "in reality the nucleus of a Caledonian folding range" (Koch 1929, p. 60, fig. 20). However, at this time the gneisses of the inner fjords between Scoresby Sund and Kejser Franz Joseph Fjord were still considered to be Archaean. Meanwhile, British geologists working in the inner part of the Kong Oscar Fjord region compared the gneisses and metasedimentary rocks of the so called 'Central Metamorphic Complex' to the Lewisian and Dalradian of Scotland, and concluded that the Caledonian orogeny was 'superficial' (Wordie 1930; Parkinson \& Whittard 1931). Helge Backlund investigated the same region, but reached a different interpretation (Backlund 1930, 1932). He proposed that Wordie's 'Archaean' granites and gneisses were the result of Caledonian granitisation and migmatisation of a varied sedimentary succession, similar to the processes of gneiss formation in Fennoscandia. Backlund's views were largely supported by Wegmann's (1935) report on the 'Caledonian orogeny', in which Wegmann speculated that any former basement to the Caledonian geosyncline (Greenlandian) would have been transformed to such a degree as to be unrecognisable (see also reviews of early work in Haller 1971, pp. 6-35).

Up to 1950 no outcrops of the Caledonian foreland had been recognised in East Greenland. However, the period 1952-1961 saw the discovery and description of foreland areas in Kronprins Christian Land in the north (Fränkl 1954, 1955), in Dronning Louise Land (Peacock 1956, 1958), and in western Gåseland in the south (Wenk 1961; see Fig. 1). All of these discoveries were incorporated into Haller's major reviews and map compilations of the East Greenland Caledonides (Haller 1970, 1971, 1983; Koch \& Haller 1971).

The area around Målebjerg $\left(73^{\circ} 27^{\prime} N\right)$ was first mapped by John Haller in 1949-1950 as part of a regional investigation of western Andrée Land (Haller 1953): it was a key area for his development of the 'stockwerke' models of the Caledonian orogeny. On the basis of his studies in Andrée Land, Haller reached wide-ranging conclusions as to the nature of the Caledonian orogeny, elaborating on the earlier interpretations of Backlund (1930, 1932) and Wegmann (1935). Thus Haller (1953) stated in his English summary (p. 190) that: "The dispute as to the age of the 'Central
Metamorphic Complex' is, as far as the region of Kejser Franz Josephs Fjord is concerned, finally resolved by the present study, which shows that several stratigraphic subdivisions, recognised in the Eleonore Bay Formation, can be traced also in the gneisses, schists and marbles of the 'Central Metamorphic Complex'. The crystalline rocks of sedimentary origin represent members of the Groenlandium, metamorphosed and metasomatically altered during the Caledonian Orogeny." With respect to the area around Målebjerg, he correlated the distinctive quartzites and dolomites found there with Fränkl's (1951) 'Alpefjord Series', i.e. the lower levels of the Eleonore Bay 'Formation' (Haller 1953).

The 'Groenlandium' (also spelt Grönlandium, Groenlandian or Greenlandian) is a now obsolete term that originally encompassed all Proterozoic sedimentary (and metasedimentary) rocks of North and East Greenland (Koch 1930). Within the Caledonides of East Greenland it was considered to be made up entirely of the Eleonore Bay 'Formation' and equivalents. Thus, Haller envisaged the sedimentary rocks of the present-day Målebjerg window, together with those of the structurally overlying Niggli Spids and Hagar Bjerg thrust sheets and Franz Joseph allochthon, to form parts of a single stratigraphical succession. The gneisses, which he viewed originally as synorogenic granites, formed parts of the mobilised infrastructure (see below). This basic interpretation remained essentially unchanged in Haller's detailed studies of nearby areas (Wenk \& Haller 1953; Haller 1955), and was only slightly modified in his later regional descriptions (Haller 1970, 1971, 1983; Koch \& Haller 1971).

Haller's early observations in the crystalline rocks of the inner fjords and nunatak region (Haller 1953, 1955, 1956; Wenk \& Haller 1953), and those of his coworkers, were all interpreted within the context of the 'stockwerke' concept. A series of categorical statements in their published descriptions appear to be aimed particularly at countering the interpretations of British geologists. Thus they stated: "The Archaean basement of the Upper Algonkian-Ordovician series of deposits has hitherto not been found anywhere in Central East Greenland" (Haller 1956, p. 160); "the geologists participating in the investigations agree that the base of the Eleonore Bay Group is not to be found within the central zone of the Caledonides" (Wenk 1961, p. 8); "The granitic and migmatitic infrastructure, in its present state of preservation, is not older, but younger, than the pre-Cambrian sedimentary cover. 
The ascent of the granitic solutions, and associated thermal fronts, represented the most important act of the East Greenland orogeny" (Wenk \& Haller 1953, p. 32-33). However, within a few years these early interpretations were modified significantly, with recognition that a 'basement' to the metasedimentary rocks was in fact recognisable: "Inside the Caledonian domain, rock units which were originally from the ancient basement, represent substantial ingredients of the fold belt" (Haller \& Kulp 1962, p. 18).

The basement gneiss complexes were, nevertheless, considered to have been petrogenetically rejuvenated over large areas, and were assigned a Caledonian age. A sketch map by Haller (Haller \& Kulp 1962, fig. 3b; Haller 1971, fig. 15b) shows that the 'Niggli Spids dome' and 'Gletscherland migmatite complex' (two of the units of the 'Central Metamorphic Complex'), were now to be considered Caledonian reworked Precambrian basement rocks. However, in respect of the nappe-like convolutions of the so called 'Hagar migmatite sheet', an entirely Caledonian origin was still envisaged. In his description of these nappelike migmatite sheets Haller 1971 (p. 179) writes: "They are asymmetrical and have considerable overlaps of up to $25 \mathrm{~km}$. Regional thrusting is probably of no importance in their formation." This is essentially a re-statement of the earlier conclusion of Wenk \& Haller (1953, p. 32): "We cannot believe that these structures are due to far-reaching tectonic transport, produced by tangential compression. Their mode of occurrence, especially their diapir-like character, indicates that we are here dealing with mobile masses of the infrastructure, which have ascended and intruded into the covering sedimentary series." Many of the essential principles of the 'stockwerke' interpretation of the East Greenland Caledonides were maintained in Haller's later publications (Haller 1971, 1983). Haller does express regret, however, that the term 'synorogenic granite' had been retained on his maps for the central metamorphic complex gneisses (Koch \& Haller 1971), because it was at variance with the modified views given by Haller \& Kulp (1962) and had thus been misunderstood by many workers.

The assumption that all metasedimentary rocks in the southern part of the Caledonides were parts of the Eleonore Bay 'Formation' or 'Group' (promoted to a 'Supergroup' by Sønderholm \& Tirsgaard 1993) was retained in Haller's latest publications (1971, 1983). It was not until the 1968-1972 expeditions by the former Geological Survey of Greenland (GGU) to the Scoresby Sund region that suspicions grew that the widespread high-grade and often migmatitic metasedimentary rocks might be significantly older than the distinctive succession now known as the Eleonore Bay Supergroup. Rb-Sr whole rock isochrons and U-Pb bulk zircon determinations indicated that some granites emplaced into the metasediments were approximately 1000 Ma old (Hansen et al. 1978; Steiger et al. 1979; Rex \& Gledhill 1981). These presumed older metasedimentary rocks, cut by the c. 1000 Ma granite suite, were therefore distinguished as the Krummedal supracrustal sequence (e.g. Henriksen \& Higgins 1969; Higgins 1974, 1988). Convincing proof that the Krummedal sequence metasedimentary rocks had experienced an early Neoproterozoic thermal event (940$910 \mathrm{Ma}$ ) not seen in the Eleonore Bay Supergroup had to await the advent of sophisticated modern geochronology, notably ion microprobe age determinations on individual zircon grains (Strachan et al. 1995; Jepsen \& Kalsbeek 1998; Kalsbeek et al. 2000; Watt et al. 2000; Leslie \& Nutman 2000, 2003).

In the mid-1970s a number of reconnaissance investigations were carried out in the general Kong Oscar Fjord region. These extended the general conclusions of the 1968-1972 investigations in the Scoresby Sund region northwards. The widespread medium- to highgrade metasedimentary successions in the Kong Oscar Fjord region were correlated with the Krummedal supracrustal sequence (Higgins 1988), and Rb-Sr whole rock isochrons on the underlying gneisses yielded Palaeoproterozoic ages (Rex \& Gledhill 1981). Two further important observations were made: (1) the distinctive quartzite in the Målebjerg window was mapped in 1976 as resting unconformably on the gneissic basement (Tage Thyrsted in Higgins et al. 1981, fig. 8), and (2) during a Survey reconnaissance helicopter flight to the Eleonore $\mathrm{S} \varnothing$ region, it was recorded that the base of the 'Slottet quartzite' at one locality was an unconformity with a basal conglomerate, rather than the supposed thrust. Unfortunately, the regional significance of these observations was not appreciated at the time.

\section{Målebjerg}

The Målebjerg area was a significant location for Haller's 'stockwerke' interpretation, in particular for the magnificent exposures of what was described as the 'zone of detachment' between the mobile granitic infrastructure and the more rigid metasedimentary superstructure (Haller 1971, photograph 47, p. 138; 


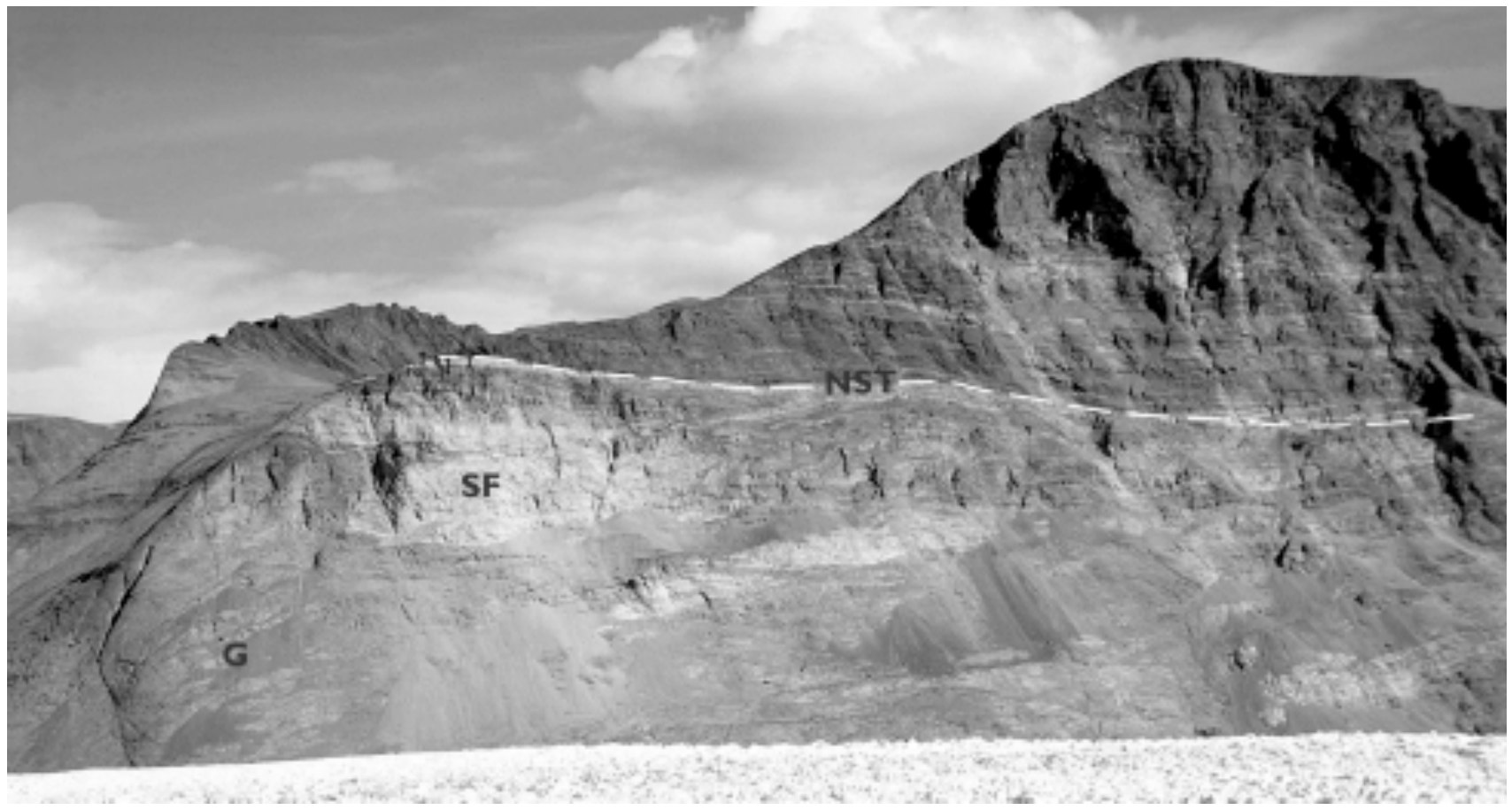

Fig. 4. The west face of Målebjerg in western Andrée Land (for location see Fig. 5). Light coloured folded quartzites $(<200 \mathrm{~m}$ thick) of the Slottet Formation (SF) unconformably overlie grey gneisses $(\mathbf{G})$ that are probably of Palaeoproterozoic age. The unconformity is strongly folded. A few metres of grey dolomite (Målebjerg Formation) occur immediately beneath the Niggli Spids thrust (NST). Overlying units of the Niggli Spids thrust sheet are dominated by massive mica schists with pale coloured carbonate-rich units (Krummedal supracrustal sequence). The summit of Målebjerg at right is $1873 \mathrm{~m}$ high, about $1500 \mathrm{~m}$ above the glacier surface in the foreground.

see also Fig. 4). Haller mapped the main lithological units in the Målebjerg area including the white quartzite now distinguished as the Slottet Formation, and recognised that they occupied an anticlinal structure (Haller 1953, 1970). He observed that the intensity of metamorphism was weaker than elsewhere and that the stratigraphy was well preserved, but he referred this quartzite and nearby marble units to the 'Basal Series' of the Eleonore Bay 'Group' (Haller 1971, p. 86).

Haller's geological and structural maps of the area around Målebjerg show several features marked with thrust symbols, some of which have no obvious significance and appear to be photogeological interpretations, while others can be identified with major structures. The most prominent structure on his maps corresponds to the NW-SE-trending, NE-dipping thrust that crosses Gemmedal (Fig. 5), a major feature now identified as the Hagar Bjerg thrust at the base of the Hagar Bjerg thrust sheet. Haller's 'zone of detachment' in the cliff of Målebjerg is not marked with a thrust symbol on his maps, but the folded quartzites of his 'zone of detachment' lie immediately beneath the Niggli Spids thrust of current usage (NST in Fig. 4).
There is no evidence that Haller considered the Målebjerg area to be a foreland window or that he suspected the presence of Lower Palaeozoic sediments. However, he was aware that a "detailed exploration of this key locality is still lacking" (Haller 1971, p. 86), and there is reason to believe that such exploration would have been carried out if Lauge Koch's expeditions had not been brought to an unexpected close after 1958.

As noted above, reconnaissance investigations in the Målebjerg area in 1976 led to recognition of an unconformity at the base of the c. $200 \mathrm{~m}$ thick quartzite, with a distinctly diverging foliation in the underlying basement gneisses ( $T$. Thyrsted in Higgins et al. 1981, fig. 8). Detailed studies in $1997-1998$ by Leslie \& Higgins (1998) established the presence of a significant foreland window (Fig. 5). Key observations included: (1) the presence of a local diamictite in depressions in the peneplained gneiss surface, now correlated with the diamictites of the Vendian Tillite Group; (2) a Skolithos-bearing quartzite (the early Cambrian Slottet Formation) unconformably overlying the gneisses and the diamictite; (3) a Lower Palaeozoic 
dolomite unit (Målebjerg Formation) above the Slottet Formation quartzite; (4) a major thrust at the top of the Målebjerg Formation (Niggli Spids thrust). These observations were confirmed by Smith \& Robertson (1999), who made additional detailed observations and measured sections in the diamictite unit (interpreted as a tillite), and in the Slottet and Målebjerg Formations (Smith et al. 2004, this volume).

\section{Eleonore Sø}

Investigation of the western nunatak region between $72^{\circ}$ and $75^{\circ} \mathrm{N}$ was for many years limited to the traverse of the Eleonore Sø area by Hans Katz in 1951 (Katz 1952, 1953), traverses by Eduard Wenk and John Haller west and south of Petermann Bjerg in 1951 and 1953 (Wenk \& Haller 1953; Haller 1956), and extensive aerial reconnaissance by John Haller. Cautious statements about what might be present in this vast nunatak area thus amounted to speculation on the basis of very limited ground information. Reviewing the possibilities subsequent to the discovery of the Caledonian foreland areas in Dronning Louise Land $\left(76^{\circ} \mathrm{N}\right.$; Peacock 1956, 1958) and in Gåseland (70N; Wenk 1961), Haller (1971, p. 195-196) suggested that the thrusts around the Gåseland window $\left(70^{\circ} \mathrm{N}\right)$ and near Charcot Land $\left(72^{\circ} \mathrm{N}\right.$; Vogt 1965$)$ had only modest displacements (20 km and $<1 \mathrm{~km}$, respectively). Recording that no further outcrops of the foreland were known, he further speculated (Haller 1971, p. 218): "Considering the structure pattern hitherto obtained from this poorly exposed and little known nunatak region, I would not be surprised if future investigators were able to trace relics of early Caledonian overthrust tectonics, on which the present pattern of main folding was then superimposed." He continues: "However, the main Caledonian structures displayed in the wellexplored fjord region are definitely not far travelled; on the contrary, they appear to be autochthonous, initiated and caused by the rise of the migmatite front resulting in a 'stockwerk' folded belt."

On the basis of his 1951 traverse of the Eleonore Sø region, Katz had observed that the low grade sedimentary rocks at Eleonore $\mathrm{S} \varnothing$ "are of the same type as those of the Eleonore Bay Formation of the fjord zone"

Fig. 5. Geological map of the Målebjerg area, after maps and interpretations of Leslie \& Higgins (1998, 1999). Legend below figure illustrates the new thrust terminology.

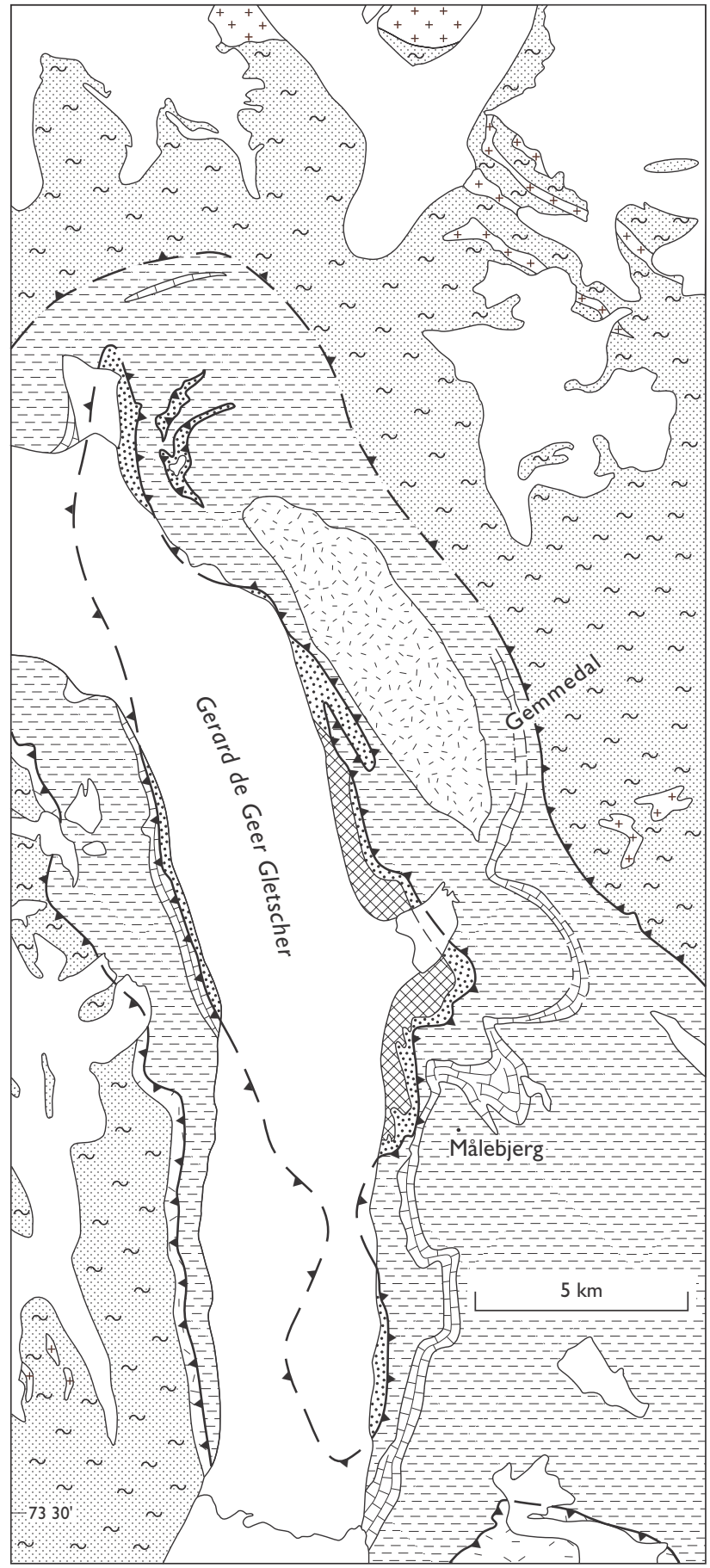

\begin{tabular}{|c|c|}
\hline+++ & Granite - $930 \mathrm{Ma}$ or Caledonian \\
\hline$\sim$ & Krummedal metasediments (Mesoproterozoic) \\
\hline-1 & Orthogneiss (Palaeoproterozoic) \\
\hline$\perp \perp$ & Thrust \\
\hline & Krummedal metasediments (Mesoproterozoic) \\
\hline 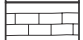 & Carbonate (Krummedal sequence) \\
\hline 准 & Orthogneiss (Palaeoproterozoic) \\
\hline$\Lambda \perp$ & Thrust \\
\hline$\because \because$ & Målebjerg and Slottet Formations \\
\hline$m$ & Orthogneiss (Palaeoproterozoic) \\
\hline
\end{tabular}




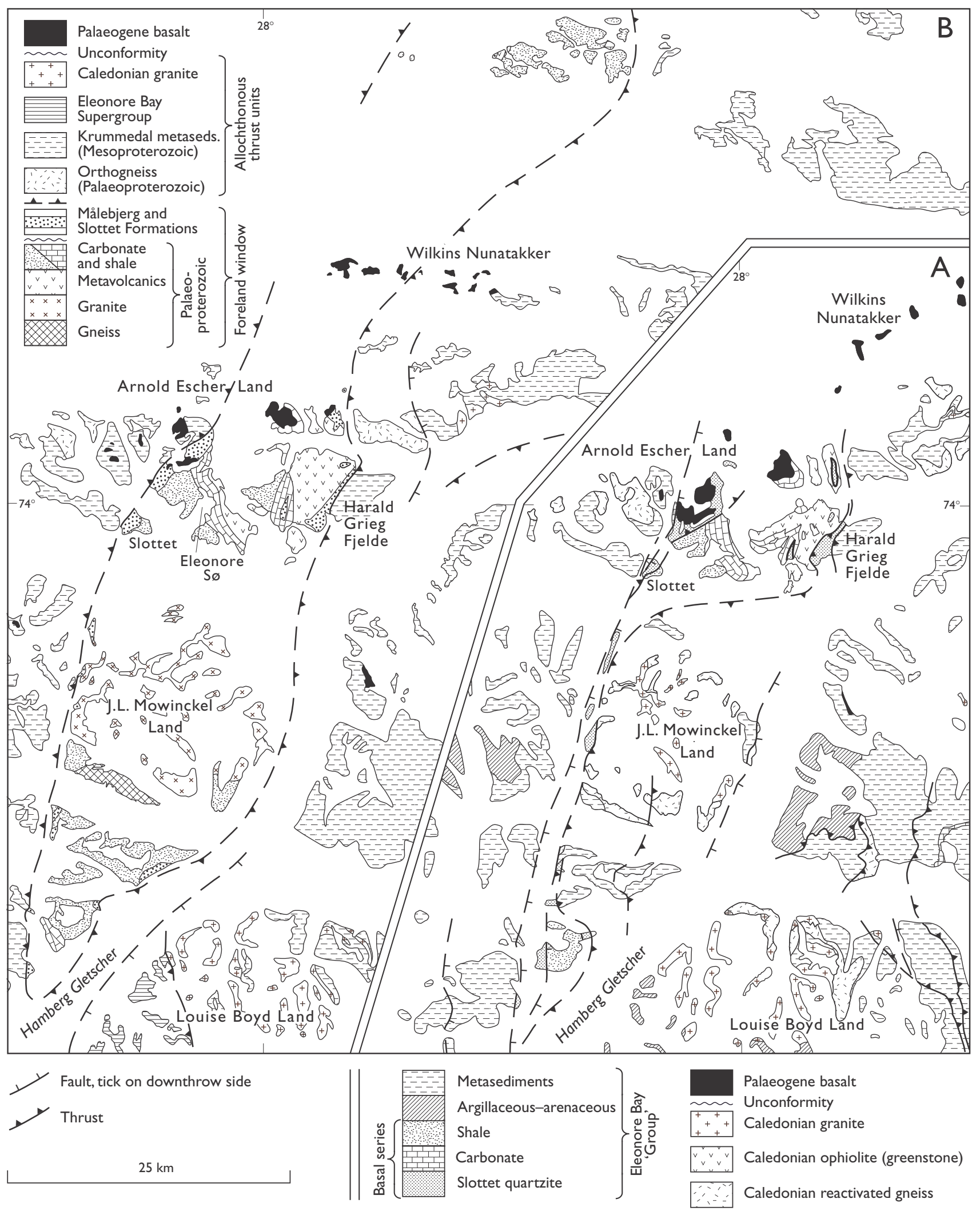

Fig. 6. Geological maps of the Eleonore $\$ \varnothing$ area, at the same scale but with slightly different topographic bases. A: Redrawn after maps and interpretations of Katz (1952), Haller (1970, 1971) and Koch \& Haller (1971). Note legend below figure assigns all sediments and metasedimentary rocks to the Eleonore Bay 'Group'. B: Redrawn after maps and interpretations of Leslie \& Higgins (1998, 1999), using a modern topographic base. Legend at top left distinguishes foreland lithologies from allochthonous thrust units. 
(Katz 1953, p. 12). The associated volcanic rocks were interpreted as ophiolitic intrusions and of the same age as the tillites of the fjord zone. While Katz correctly depicted a thrust at the west side of Harald Grieg Fjelde (Fig. 6A), he considered it to be of Devonian age (this thrust corresponds to the major thrust contact on the east side of the window above the Målebjerg Formation dolomites; Fig. 6B). The map in Katz (1953) also shows a continuous thrust contact at the base of his 'Slottet Quartzite' (Fig. 6A), with the internal structure of the quartzite depicted on his crosssections (Katz 1953, tafel 4) as discordant to the 'thrust' at the base. It was Katz's interpretation of this prominent quartzite unit as equivalent to the lower part of the Eleonore Bay 'Formation' that led him to introduce the basal thrust, because the quartzite lay structurally above the sedimentary rocks he viewed as correlateable with the upper part of the Eleonore Bay 'Formation'. Katz's cross-section of the Eleonore $\$ \varnothing$ region (1953, tafel 4) does indicate tectonic contacts at both margins of the present window, but his preferred interpretation was that the rock units occupied a graben.

Based on the work of Katz, Haller initially agreed with Katz's interpretation that the Eleonore $\$ \varnothing$ sediments, which from aerial observations he had traced southwards through J.L. Mowinckel Land to Hamberg Gletscher, occupied a large post-Caledonian graben structure (Haller 1956, p. 161). Most geologists that have worked in East Greenland have come across the widespread and often large erratic blocks of Skolithosbearing quartzites, and Haller (1971, fig. 48) had plotted observations of these quartzites, and inferred that the source areas lay beneath the Inland Ice. However, he clearly did not make any link between the Skolithos erratic boulders and the 'Slottet Quartzite' of Katz (1952, 1953), since he placed this latter unit in his 'Basal Series' of the Eleonore Bay 'Formation'. Summarising the situation at Eleonore $S \varnothing$, Haller writes of the nonmetamorphic dolomites and quartzites at Eleonore Sø as being associated with greenschists that Katz had interpreted as Caledonian ophiolites. He notes that the region in which the outcrops are found is bounded on both sides by tectonic lineaments, and he writes (Haller 1971, p. 86-87) "it is open to question whether we are concerned here with parts of the overridden Caledonian foreland, similar to the Gaaseland 'window', or not."

The structures distinguished by Haller (1970, 1971) in the vicinity of Eleonore $S \varnothing$ compared to those mapped by Leslie \& Higgins (1998, 1999) are shown in Fig. 6. The only thrust correctly depicted by Haller, who here followed the usage of Katz (1952), is the east-dipping structure on the east side of the window at Harald Grieg Fjelde. At this locality, high-grade metasedimentary rocks in the hanging wall lie structurally above low-grade carbonates and quartzites in the foot wall. In view of the difficulties of access to the region in the 1950s, and the lack of isotopic age determinations, it is not surprising that the ages attributed to the rock units in the Eleonore $S \varnothing$ region by Katz and Haller have since proved to be incorrect. However, the thrust that marks the west side of the window is depicted on Haller's maps as a major normal fault, whereas the other thrusts shown on Haller's interpretation (Fig. 6A) correspond to the unconformity at the base of the 'Slottet Quartzite', the presentday Slottet Formation. It is, perhaps, surprising that Katz did not apparently examine the base of the quartzite unit, which is an obvious unconformity in the field, and often has a basal conglomerate. His erroneous interpretation of this unconformity as a thrust contact does give the impression of an arched thrust on Haller's structural maps (e.g. Haller 1971, fig. 58), and has been taken by some authors as evidence that Haller 'discovered' the window (cf. Hartz et al. 2001). However, as noted above, Haller (1971) considered it "open to question".

Only a few geologists have visited the Eleonore Sø region since Katz's 1951 visit, but it was not until the Survey's 1997-1998 regional mapping expedition that detailed field studies led to the regional delineation of the basal unconformity of the 'Slottet Quartzite'. The authors of this article retraced one of Katz's traverses eastwards towards Harald Grieg Fjelde, and observed that the basal contact of the quartzite was in fact conformable to the bedding within the quartzite rather than discordant as in Katz's profiles (Katz 1952). The quartzites were observed to contain well-preserved sedimentary structures, and the first in situ finds of Skolithos were found just west of the thrust at Harald Grieg Fjelde. The unconformity surface, subsequently studied at several localities, proved to be a clean undisturbed contact (Fig. 7) with a basal conglomerate up to $1.5 \mathrm{~m}$ thick often present. In nearly every section of the quartzites examined, in situ long Skolithos burrows were observed, and these demonstrate that the sequence now termed the Slottet Formation (Smith et al. 2004, this volume) is of Lower Cambrian age (Crimes 1992). A Cambrian-Ordovician age can therefore be assumed for the thin dolomite sequence of the Målebjerg Formation, which conformably overlies 


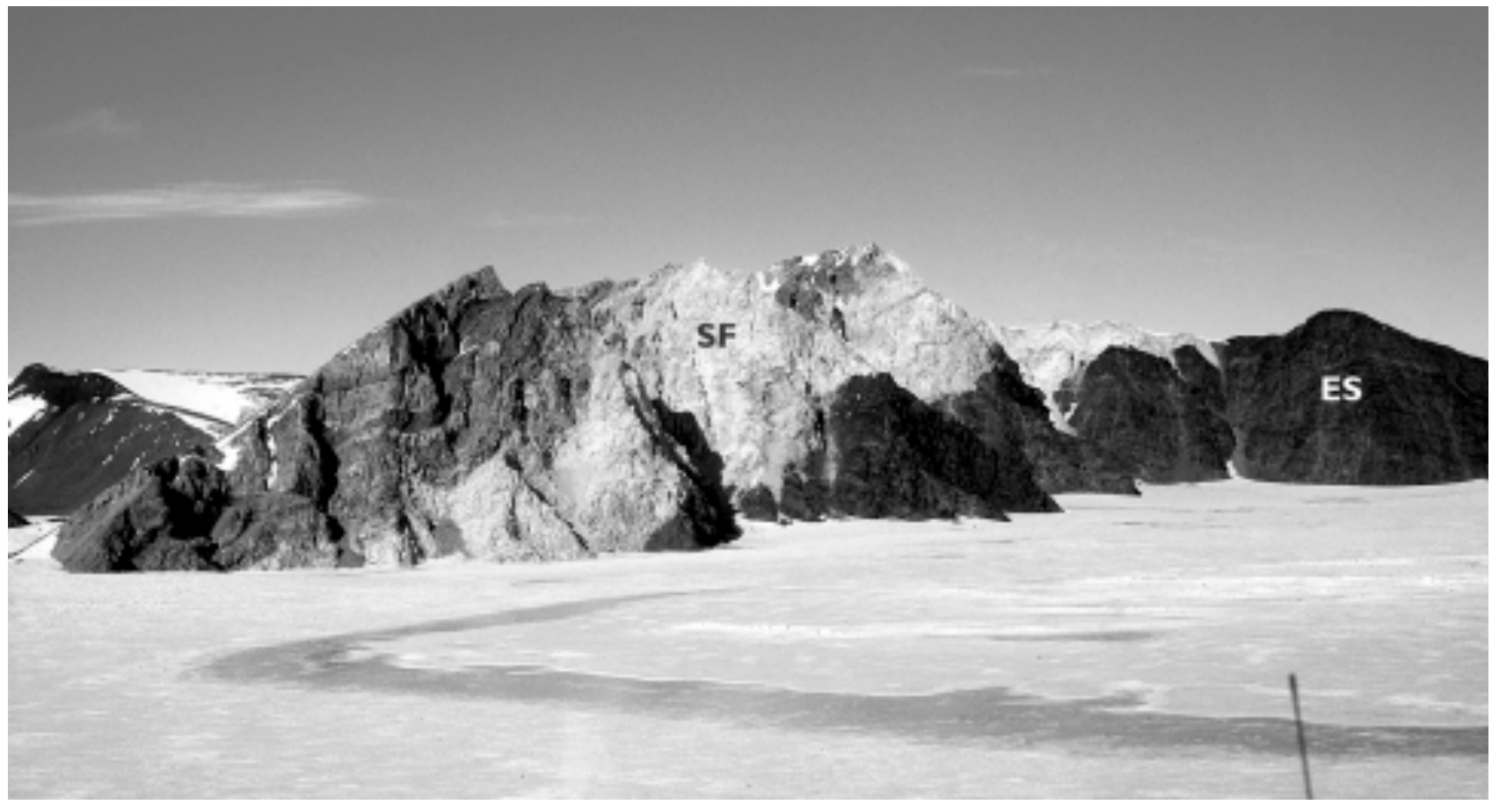

Fig. 7. The nunatak Slottet in the Eleonore $S \varnothing$ window, looking northwards. The white (lower) and dark (upper) quartzites of the Lower Cambrian Slottet Formation (SF: $350 \mathrm{~m}$ thick) rest unconformably on dark coloured Palaeoproterozoic clastic sediments of the Eleonore Sø volcano-sedimentary complex (ES). The highest summit of Slottet is $1933 \mathrm{~m}$ high, about $600 \mathrm{~m}$ above the glacier surface.

the Slottet Formation and immediately underlies the thrust (Leslie \& Higgins 1998, 1999; Smith et al. 2004, this volume). On the west side of the window, the west-dipping thrust contact is well exposed and associated with thick developments of mylonites. A clear definition of the entire thrust system bordering the window was established for the first time during the 1997-1998 mapping (Fig. 6B). Finds of low grade volcanic rocks in eastern J.L. Mowinckel Land have extended the known distribution of their occurrence considerably, such that the eastern marginal thrust of the window can now be placed parallel to the glacier to the east of J.L. Mowinckel Land. Exposures of characteristic rock types (low-grade volcanic rocks and Skolithos-bearing quartzites) observed as far north as nunataks at $74^{\circ} 25^{\prime} \mathrm{N}$ (Fig. 6B) show that the NNESSW extent of the Eleonore S $\varnothing$ window is at least 125 $\mathrm{km}$. The volcanic succession (pillow lavas and tuffs) and associated sedimentary rocks (thick dolomites and dolomite breccias, sandstones and shales) that are unconformably overlain by the Slottet Formation quartzites are intruded locally by quartz porphyry bodies, dated by SHRIMP analyses of zircon to $c .1950$ Ma (F. Kalsbeek, personal communication 2000). The Eleonore $S \varnothing$ volcano-sedimentary rocks are thus Pal- aeoproterozoic or older in age, and can be broadly compared with the volcano-sedimentary rocks of the Charcot Land window at $c .72^{\circ} \mathrm{N}$ and the foreland exposures of the Hamberg Gletscher complex (volcanic rocks and associated gabbros) at $c .73^{\circ} \mathrm{N}$ (Fig. 1; Higgins et al. 2001).

\section{Discussion}

The exceptional exposures in the extensive fjord system and nunataks of the Kong Oscar Fjord region $\left(72^{\circ}-\right.$ $75^{\circ} \mathrm{N}$ ), and the long series of geological expeditions led by Lauge Koch (1926-1958), have deservedly led to recognition of the East Greenland Caledonides as a spectacular example of an orogenic belt. This is in large part a tribute to the superb compilations of data presented by John Haller (Haller 1970, 1971; Koch \& Haller 1971). Development of new models for the East Greenland Caledonides, to replace the 'stockwerke' concept, has been a gradual process extending over a period of some 30 years (1968-1998), during which the entire $1300 \mathrm{~km}$ length of the orogen has been remapped as part of the Survey's regional 1:500 000 mapping project. During this extended period of re- 
search, most of the assumptions built into Haller's (1970, 1971) 'stockwerke' concept of an in situ Caledonian orogenic belt have been queried or refuted, and the new interpretations confirmed by increasingly sophisticated isotopic age determinations.

Prior to the Survey's 1997-98 expeditions the existence of far-travelled thrust sheets had not been demonstrated in the Kong Oscar Fjord region. With discovery of the Eleonore $S \varnothing$ and Målebjerg windows, and distinction of a thrust pile with hundreds of kilometres of west-north-west thrust displacement (Henriksen 1998, 1999; Leslie \& Higgins 1998, 1999; Elvevold et al. 2000; Higgins et al. 2004), the 'stockwerke' concept of in situ Caledonian orogenesis can finally be pronounced dead and laid to rest. Restoration of the thrust sheets to their approximate original locations implies that the focus of Caledonian orogenesis, i.e. the collision of Laurentia with Baltica, took place several hundred kilometres east-south-east of the orogenic belt now preserved onshore in East Greenland.

Wordie (1930) and Parkinson \& Whittard (1931) were, in fact, partly correct when they compared the crystalline gneisses of the inner fjord region of East Greenland to the Archaean Lewisian gneisses of Scotland. The former have yielded Archaean and Proterozoic protolith ages, with Archaean gneiss complexes extending throughout the inner part of the Scoresby Sund region and northwards to southern Suess Land $\left(72^{\circ} 50^{\prime} \mathrm{N}\right)$. Farther north the orthogneisses have yielded Palaeoproterozoic protolith ages which relate to an important episode of regional Palaeoproterozoic crustformation well documented throughout the northern half of the East Greenland Caledonides (Kalsbeek et al. 1993, 1999). It follows that Haller (1953) was wrong in attributing the formation of the orthogneisses to rising fronts of Caledonian migmatisation that transformed metasedimentary rocks of the Eleonore Bay 'Formation'. Haller's later re-interpretation of these gneisses as Caledonian reworked basement rocks was close to the present-day interpretation (Haller \& Kulp 1962; Haller 1971).

John Haller was of Swiss nationality, educated in Switzerland, and obviously familiar with the major thrusts and fold nappes of the Alpine orogenic belt. His earliest 1949-1951 studies in East Greenland were in Andrée Land (Haller 1953), and his main conclusions were presented as a confirmation and elaboration of the interpretations of H.G. Backlund and C.E. Wegmann. He was already committed to the idea of widespread transformation of a single metasedimentary succession (Eleonore Bay 'Group') by the vertical rise of mobile migmatitic bodies, a view that was developed during his subsequent field work, and elegantly presented as the 'stockwerke' concept (Haller 1970, 1971). Haller's wide-ranging observations on the ground and from the air, and Katz's observations around Eleonore $S \varnothing$, were all interpreted within the context of the basic 'stockwerke' model. Thus the Palaeoproterozoic volcano-sedimentary succession of the Eleonore $S \varnothing$ window and the thin Lower Palaeozoic successions of the Målebjerg and Eleonore $\mathrm{S} \varnothing$ windows were referred to the Eleonore Bay 'Group'. An unconformity at the base of the 'Slottet quartzite' in the Eleonore Sø window, presumably not examined very closely, was interpreted as a major thrust in order to force the stratigraphy to fit into the model. The displacements on the major thrusts that were recognised were grossly underestimated, perhaps in order not to upset the assumption that "the main Caledonian structures displayed in the well-explored fjord region are definitely not far travelled; on the contrary, they appear to be autochthonous" (Haller 1971, p. 218).

While the 'stockwerke' model of intense in situ granitisation is no longer tenable, the Caledonian orogeny in East Greenland was certainly not the 'superficial' orogeny envisaged by the early British geologists. The Precambrian orthogneiss complexes, together with the overlying metasedimentary successions, have experienced high-grade Caledonian metamorphism and intense reworking during the regional Caledonian compressive deformation that produced major westward propagating thrust sheets. Caledonian granites generated by melting of Mesoproterozoic sediments are widespread in the Hagar Bjerg thrust sheet, but absent in the lower Niggli Spids thrust sheet. The dominant fabric in the Archaean and Palaeoproterozoic orthogneisses of the thrust sheets is today interpreted in many areas to be essentially Caledonian, which as a concept is not greatly different from the 'Caledonian petrogenetic rejuvenation' envisaged by Haller \& Kulp (1962, p. 18). However, despite Caledonian reworking, the orthogneisses of the crystalline complexes still yield Archaean and Palaeoproterozoic protolith ages, and in low strain areas relicts of the Precambrian foliation cut by discordant amphibolite dykes are preserved (Higgins et al. 1981, p. 37-38).

The assumption that all metasedimentary rocks in the southern half of the East Greenland Caledonides were variably transformed parts of the Eleonore Bay 'Group', was not questioned until GGU's work in the Scoresby Sund region in 1968-1972. Although then 
based on imprecise Rb-Sr and U-Pb ages (Rex \& Gledhill 1974; Hansen et al. 1978; Steiger et al. 1979), GGU's investigations led to distinction of two sedimentary successions (Henriksen \& Higgins 1969, 1976; Higgins 1974, 1988). The widespread high-grade metasedimentary rocks that hosted c. 1000 Ma augen granites were ascribed to the Krummedal supracrustal sequence, whereas the high-grade to non-metamorphic Eleonore Bay Supergroup appeared to be affected only by Caledonian metamorphism and deformation. This viewpoint did not go unchallenged, and diverging interpretations have continued to be expressed (Peucat et al. 1985; Hartz \& Andresen 1995; Andresen \& Hartz 1998; Hartz et al. 2000).

Recent ion microprobe zircon studies have now confirmed the widespread distribution of a distinctive 940-910 Ma granite suite hosted by the high-grade, commonly migmatitic, Krummedal sequence of the Hagar Bjerg thrust sheet (Jepsen \& Kalsbeek 1998; Kalsbeek et al. 2000; Leslie \& Nutman 2000; Watt et al. 2000; Watt \& Thrane 2001). A later granite suite, hosted by both the Krummedal sequence and the lowest part of the Eleonore Bay Supergroup, is Caledonian in age (Rex \& Gledhill 1981; Hartz et al. 2001; Kalsbeek et al. 2001a, b; White et al. 2002).

The most dramatic revelation of the recent Survey mapping is that the $18.5 \mathrm{~km}$ thick NeoproterozoicOrdovician succession preserved in the Franz Joseph allochthon of the Hagar Bjerg thrust sheet structurally overlies a partly equivalent $<400 \mathrm{~m}$ thick sequence preserved in the Målebjerg window (Fig. 4). Higgins et al. (2001, fig. 8) demonstrated the similarities of the restricted foreland succession of the Målebjerg window with that in the Eleonore $S \varnothing$ window and other foreland areas preserved along the western margin of the East Greenland Caledonides. It follows that the allochthonous and very thick Eleonore Bay Supergroup - Tillite Group - Kong Oscar Fjord Group succession must have been laid down in a completely different sedimentary environment a substantial distance to the east of the restricted sequence deposited on the foreland craton. The succession preserved in the Franz Joseph allochthon of East Greenland exhibits broad similarities with the major Neoproterozoic - Lower Palaeozoic sedimentary successions of Svalbard, NW Scotland and Newfoundland that were deposited along the western passive margin of the Iapetus ocean (e.g. Swett \& Smit 1972; Soper 1994). In East Greenland the preserved remnants of this basin were displaced at least $200 \mathrm{~km}$, and possibly as much as $400 \mathrm{~km}$, westnorth-west across the Laurentian margin to structur- ally overlie their thin foreland equivalents, a Caledonian shortening across the orogenic belt estimated at 40-60\% (Higgins \& Leslie 2000; Higgins et al. 2001, 2004). As noted above, restoration of the thrust sheets to their approximate original locations implies that the collision of Laurentia with Baltica took place several hundred kilometres east-south-east of the orogenic belt now preserved onshore in East Greenland.

The models of the Caledonian orogen presented by Hartz \& Andresen (1995) and Andresen et al. (1998), which invoked upward and lateral movement of light, low viscosity, lower crustal material towards the region of maximum crustal extension, a process compared to Haller's 'stockwerke' concept, neglect the significance of Caledonian thrusting. Following the Survey's demonstration of the existence of the foreland windows and the presence of major thrusts at Caledonian symposiums held in Copenhagen (Frederiksen \& Thrane 1998, 1999), a considerably revised model for the orogen was presented by Hartz et al. (2001). While the thrust terminology employed by Hartz et al. (2001) has similarities with that of Elvevold et al. (2000), there are many differences in interpretation. Some boundaries on their map (Hartz et al. 2001, fig.1) appear to have been adopted from Koch \& Haller's (1971) obsolete maps, and, for example, the west-dipping thrust of the Eleonore Sø window is incorrectly indicated as an east-dipping extensional fault (cf. Fig. 6).

John Haller's contributions to the understanding of the East Greenland Caledonides are considerable (see e.g. Henriksen \& Higgins 1993; Schwarzenbach 1993). However, although he did not discover the Målebjerg and Eleonore Sø windows or identify the Lower Palaeozoic rock units, many of his observations, in retrospect, support such an interpretation. Unfortunately, Haller's emphasis on the autochthonous in situ origin of the crystalline complexes led him to deny that significant thrusting was involved in the central fjord zone, and to underestimate displacements on the thrusts that were observed in Gåseland, near Charcot Land, around Eleonore $\$ \varnothing$, and around Målebjerg in Andrée Land.

\section{Acknowledgements}

The helpful comments of the two reviewers, Brian Chadwick and Arild Andresen, are gratefully acknowledged, and have resulted in correction of a number of errors and improvements to the original text. 


\section{References}

Andresen, A. \& Hartz, E.H. 1998: Basement-cover relationships and orogenic evolution in the central East Greenland Caledonides. GFF 120, 191-198. Stockholm: Geological Society of Sweden.

Andresen, A., Hartz, E. \& Vold, J. 1998: A late orogenic extensional origin for the infrastructural gneiss domes of the East Greenland Caledonides $\left(72^{\circ}-74^{\circ} \mathrm{N}\right)$. Tectonophysics 285, 353-369.

Backlund, H.G. 1930: Contributions to the geology of Northeast Greenland. Meddelelser om Grønland 74(11), 207-296.

Backlund, H.G. 1932: Das Alter des 'Metamorphen Komplexes' von Franz Josef Fjord in Ost-Grönland. Meddelelser om Grønland 87(4), 119 pp.

Best, M.G. 2003: Igneous and metamorphic petrology (2nd edit.), 729 pp. Oxford: Blackwell Publishing.

Cowie, J.W. \& Adams, P.J. 1957: The geology of the CambroOrdovician rocks of central East Greenland. Part 1. Stratigraphy and structure. Meddelelser om Grønland 153(1), 193 pp.

Crimes, T.P. 1992: The record of trace fossils across the Proterozoic-Cambrian boundary. In: Lipps, J.H. \& Signor, P.W. (eds): Origin and early evolution of the Metazoa, 177-202. New York: Plenum Press.

Elvevold, S. et al. 2000: Tectonic architecture of the East Greenland Caledonides $72^{\circ}-74^{\circ} 30^{\prime}$ N. Danmarks og Grønlands Geologiske Undersøgelse Rapport 2000/88, 34 pp.

Escher, J.C. \& Jones, K.A. 1998: Caledonian thrusting and extension in Frænkel Land, East Greenland $\left(72^{\circ} 30^{\prime}-73^{\circ} \mathrm{N}\right)$ : preliminary results. In: Higgins, A.K. \& Frederiksen, K.S. (eds): Caledonian geology of East Greenland $72^{\circ}-74^{\circ} \mathrm{N}$ : preliminary reports from the 1997 expedition. Danmarks og Grønlands Geologiske Undersøgelse Rapport 1998/28, 29-42.

Escher, J.C. \& Jones, K.A. 1999: Caledonian geology of Frænkel Land and adjacent areas $\left(73^{\circ} 00^{\prime}-73^{\circ} 30^{\prime} \mathrm{N}\right)$, East Greenland. In: Higgins, A.K. \& Frederiksen, K.S. (eds): Geology of East Greenland $72^{\circ}-75^{\circ} \mathrm{N}$, mainly Caledonian: preliminary reports from the 1998 expedition. Danmarks og Grønlands Geologiske Undersøgelse Rapport 1999/19, 27-36.

Fränkl, E. 1951: Die untere Eleonore Bay Formation im Alpefjord. Meddelelser om Grønland 151(6), 15 pp.

Fränkl, E. 1954: Vorläufige Mitteilung über die Geologie von Kronprins Christians Land (NE-Grönland, zwischen $80^{\circ}-81^{\circ} \mathrm{N}$ und $\left.19^{\circ}-23^{\circ} \mathrm{W}\right)$. Meddelelser om Grønland 116(2), $85 \mathrm{pp}$.

Fränkl, E. 1955: Weitere Beiträge zur Geologie von Kronprins Christians Land (NE-Grönland, zwischen $80^{\circ}$ und $80^{\circ} 30^{\prime} \mathrm{N}$ ). Meddelelser om Grønland 103(7), 35 pp.

Frederiksen, K.S. \& Thrane, K. (eds) 1998: Symposium on Caledonian geology in East Greenland. Abstract volume. Danmarks og Grønlands Geologiske Undersøgelse Rapport 1998/46, 55 pp.

Frederiksen, K.S. \& Thrane, K. (eds) 1999: Second symposium on East Greenland geology, mainly Caledonian. Abstract volume. Danmarks og Grønlands Geologiske Undersøgelse Rapport 1999/21, $64 \mathrm{pp}$.

Haller, J. 1953: Geologie und Petrographie von West-Andrées Land und Ost-Frænkels Land (NE-Grönland). Meddelelser om Grønland 113(5), 196 pp.
Haller, J. 1955: Der 'Zentrale Metamorphe Komplex' von NEGrönland. Teil I. Der geologische Kart von Suess Land, Gletscherland und Goodenoughs Land. Meddelelser om Grønland 73, I(3), 174 pp.

Haller, J. 1956: Geologie der Nunatakker Region von ZentralOstgrönland. Meddelelser om Grønland 154(1), 172 pp.

Haller, J. 1970: Tectonic map of East Greenland (1:500,000). An account of tectonism, plutonism and volcanism in East Greenland. Meddelelser om Grønland 171(5), 286 pp.

Haller, J. 1971: Geology of the East Greenland Caledonides, 413 pp. London: Interscience.

Haller, J. 1979: Himalayan orogenesis in perspective. In: Verma, P.A. (ed.): Metamorphic rock sequences of the Eastern Himalaya, i-xxxiv. Calcutta: K.P. Bagchi \& Co.

Haller, J. 1983: Geological map of Northeast Greenland $75^{\circ}-82^{\circ}$ N.Lat. 1:1,000,000. Meddelelser om Grønland 200(5), 22 pp.

Haller, J. \& Kulp, J.L. 1962: Absolute age determinations in East Greenland. Meddelelser om Grønland 171(1), 77 pp.

Hambrey, M.J. \& Spencer, A.M. 1987: Late Precambrian glaciation of central East Greenland. Meddelelser om Grønland Geoscience 19, 50 pp.

Hansen, B.T., Higgins, A.K. \& Bär, M.-T. 1978: Rb-Sr and U-Pb age patterns in polymetamorphic sediments from the southern part of the East Greenland Caledonides. Bulletin of the Geological Society of Denmark 27, 55-62.

Hartz, E. \& Andresen, A. 1995: Caledonian sole thrust of central East Greenland: a crustal scale Devonian extensional detachment. Geology 23, 637-640.

Hartz, E.H., Andresen, A., Martin, M.W. \& Hodges, K.V. 2000: U$\mathrm{Pb}$ and ${ }^{40} \mathrm{Ar} /{ }^{39} \mathrm{Ar}$ constraints on the Fjord Region Detachment Zone: a long-lived extensional fault in the central East Greenland Caledonides. Journal of the Geological Society (London) 157, 795-809.

Hartz, E.H., Andresen, A., Hodges, K.V. \& Martin, M.W. 2001: Syncontractional extension and exhumation of deep crustal rocks in the East Greenland Caledonides. Tectonics 20, 58-77.

Henriksen, N. 1998: North-East Greenland 1997-1998: a new 1:500 000 mapping project in the Caledonian fold belt $\left(72^{\circ}-\right.$ $75^{\circ} \mathrm{N}$ ). Geology of Greenland Survey Bulletin 180, 119-127.

Henriksen, N. 1999: Conclusion of the 1:500 000 mapping project in the Caledonian fold belt in North-East Greenland. Geology of Greenland Survey Bulletin 183, 10-22.

Henriksen, N. \& Higgins, A.K. 1969: Preliminary results of mapping in the crystalline complex around Nordvestfjord, Scoresby Sund, East Greenland. Rapport Grønlands Geologiske Undersøgelse 21, 5-20.

Henriksen, N. \& Higgins, A.K. 1976: East Greenland Caledonides. In: Escher, A. \& Watt, W.S. (eds): Geology of Greenland, 182246. Copenhagen: Geological Survey of Greenland.

Henriksen, N. \& Higgins, A.K. 1993: John Haller and GGU (The Geological Survey of Greenland). In: Schwarzenbach, F.H. (ed.): Towards new horizons, John Haller 1927-1984, 88-94. Zürich: Verlag der Fachvereine \& Schweizerische Stiftung für Forschungen.

Higgins, A.K. 1974: The Krummedal supracrustal sequence around inner Nordvestfjord, Scoresby Sund, East Greenland. Rapport Grønlands Geologiske Undersøgelse 67, 34 pp. 
Higgins, A.K. 1988: The Krummedal supracrustal sequence in East Greenland. In: Winchester, J.A. (ed.): Later Proterozoic stratigraphy of the northern Atlantic regions, 86-96. Glasgow and London: Blackie and Son Ltd.

Higgins, A.K. \& Leslie, A.G. 2000: Restoring thrusting in the East Greenland Caledonides. Geology 28, 1019-1022.

Higgins, A.K., Friderichsen, J.D. \& Thyrsted, T. 1981: Precambrian metamorphic complexes in the East Greenland Caledonides $\left(72^{\circ}-74^{\circ} \mathrm{N}\right)$ - their relationships to the Eleonore Bay Group and Caledonian orogenesis. Rapport Grønlands Geologiske Undersøgelse 104, 46 pp.

Higgins, A.K., Leslie, A.G. \& Smith, M.P. 2001: Neoproterozoic Lower Palaeozoic stratigraphical relationships in the marginal thin-skinned thrust belt of the East Greenland Caledonides: comparisons with the foreland of Scotland. Geological Magazine 138, 143-160.

Higgins, A.K. et al. 2004: The foreland-propagating thrust architecture of the East Greenland Caledonides $72^{\circ}-75^{\circ} \mathrm{N}$. Journal of the Geological Society (London) 161, 1009-1026.

Jepsen, H.F. \& Kalsbeek, F. 1998: Granites in the Caledonian fold belt of East Greenland. In: Higgins, A.K. \& Frederiksen, K.S. (eds): Caledonian geology of East Greenland $72^{\circ}-74^{\circ} \mathrm{N}$ : preliminary reports from the 1997 expedition. Danmarks og Grønlands Geologiske Undersøgelse Rapport 1998/28, 73-82.

Kalsbeek, F., Nutman, A.P. \& Taylor, P.N. 1993: Palaeoproterozoic basement province in the Caledonian fold belt of NorthEast Greenland. Precambrian Research 63, 163-178.

Kalsbeek, F., Nutman, A.P., Escher, J.C., Friderichsen, J.D., Hull, J.M., Jones, K.A. \& Pedersen, S.A.S. 1999: Geochronology of granitic and supracrustal rocks from the northern part of the East Greenland Caledonides: ion microprobe U-Pb zircon ages. Geology of Greenland Survey Bulletin 184, 31-48.

Kalsbeek, F., Thrane, K., Nutman, A.P. \& Jepsen, H.F. 2000: Late Mesoproterozoic to early Neoproterozoic history of the East Greenland Caledonides: evidence for Grenvillian orogenesis? Journal of the Geological Society (London) 157, 1215-1225.

Kalsbeek, F., Jepsen, H.F. \& Nutman, A.P. 2001a: From source migmatites to plutons: tracking the origin of $c .435$ Ma granites in the East Greenland Caledonian orogen. Lithos 57, 121.

Kalsbeek, F., Jepsen, H.F. \& Jones, K.A. 2001b: Geochemistry and petrogenesis of S-type granites in the East Greenland Caledonides. Lithos 57, 91-109.

Katz, H.R. 1952: Ein Querschnitt durch die Nunatakzone Ostgrönlands (ca. $74^{\circ}$ n.B.). Ergebnisse einer Reise vom Inlandeis (in Zusammenarbeit mit den Expéditions Polaires Françaises von P.-E. Victor) ostwärts bis in die Fjordregion, ausgeführt im Sommer 1951. Meddelelser om Grønland 144(8), 65 pp.

Katz, H.R. 1953: Journey across the nunataks of central East Greenland. Arctic 6(1), 3-14.

Koch, L. 1929: The geology of East Greenland. Meddelelser om Grønland 73, II(1), 204 pp.

Koch, L. 1930: Die tektonische Entwicklung Grönlands. Geologische Rundschau 21, 345-347

Koch, L. \& Haller, J. 1971: Geological map of East Greenland $72^{\circ}-76^{\circ}$ N. Lat. $(1: 250,000)$. Meddelelser om Grønland $\mathbf{1 8 3}$ 26 pp., 13 maps.

Larsen, P.-H. \& Bengaard, H.-J. 1991: Devonian basin initiation in East Greenland: a result of sinistral wrench faulting and Caledonian extensional collapse. Journal of the Geological Society (London) 148, 355-368.

Leslie, A.G. \& Higgins, A.K. 1998: On the Caledonian geology of Andrée Land, Eleonore $\$ \varnothing$ and adjacent nunataks $\left(73^{\circ} 30^{\prime}-\right.$ $\left.74^{\circ} \mathrm{N}\right)$, East Greenland. In: Higgins, A.K. \& Frederiksen, K.S. (eds): Caledonian geology of East Greenland $72^{\circ}-74^{\circ} \mathrm{N}$ : preliminary reports from the 1997 expedition. Danmarks og Grønlands Geologiske Unders øgelse Rapport 1998/28, 11-27.

Leslie, A.G. \& Higgins, A.K. 1999: On the Caledonian (and Grenvillian) geology of Bartholin Land, Ole Rømer Land and adjacent nunataks, East Greenland. In: Higgins, A.K. \& Frederiksen, K.S. (eds): Geology of East Greenland $72^{\circ}-75^{\circ} \mathrm{N}$, mainly Caledonian: preliminary reports from the 1998 expedition. Danmarks og Grønlands Geologiske Undersøgelse Rapport 1999/19, 11-26.

Leslie, A.G. \& Nutman, A.P. 2000: Episodic tectono-thermal activity in the southern part of the East Greenland Caledonides. Geology of Greenland Survey Bulletin 186, 42-49.

Leslie, A.G. \& Nutman, A.P. 2003: Evidence for Neoproterozoic orogenesis and early high temperature Scandian deformation events in the southern East Greenland Caledonides. Geological Magazine 140, 309-333.

Parkinson, M.M.L. \& Whittard, W.F. 1931: The geological work of the Cambridge expedition to East Greenland in 1929. Quarterly Journal of the Geological Society (London) 87, 650-674.

Peacock, J.D. 1956: The geology of Dronning Louise Land, N.E. Greenland. Meddelelser om Grønland 137(7), 38 pp.

Peacock, J.D. 1958: Some investigations into the geology and petrography of Dronning Louise Land, N.E. Greenland. Meddelelser om Grønland 157(4), 139 pp.

Peucat, J.J., Tisserant, D., Caby, R. \& Clauer, N. 1985: Resistance of zircons to $\mathrm{U}-\mathrm{Pb}$ resetting in a prograde metamorphic sequence of Caledonian age in East Greenland. Canadian Journal of Earth Sciences 22, 330-338.

Rex, D.C. \& Gledhill, A.R. 1974: Reconnaissance geochronology of the infracrustal rocks of Flyverfjord, Scoresby Sund, East Greenland. Bulletin of the Geological Society of Denmark 23, 49-54.

Rex, D.C. \& Gledhill, A.R. 1981: Isotopic studies in the East Greenland Caledonides $\left(72^{\circ}-74^{\circ} \mathrm{N}\right)$ - Precambrian and Caledonian ages. Rapport Grønlands Geologiske Undersøgelse 104, 4772 .

Schwarzenbach, F.H. (ed.) 1993: Towards new horizons, John Haller 1927-1984, 128 pp. Zürich: Verlag der Fachvereine \& Schweizerische Stiftung für Forschungen.

Smith, M.P. 1991: Early Ordovician conodonts of East and North Greenland. Meddelelser om Grønland Geoscience 26, 81 pp.

Smith, M.P. \& Bjerreskov, M. 1994: The Ordovician System in Greenland. International Union of Geological Sciences Special Publication 29A, 46 pp.

Smith, M.P. \& Robertson, S. 1999: The Nathorst Land Group (Neoproterozoic) of East Greenland - lithostratigraphy, basin geometry and tectonic history. In: Higgins, A.K. \& Frederiksen, 
K.S. (eds): Geology of East Greenland $72^{\circ}-75^{\circ} \mathrm{N}$, mainly Caledonian: preliminary reports from the 1998 expedition. Danmarks og Grønlands Geologiske Undersøgelse Rapport 1999/19, 127-143.

Smith, M.P., Rasmussen, J.A., Robertson, S., Higgins, A.K. \& Leslie, A.G. 2004: Lower Palaeozoic stratigraphy of the East Greenland Caledonides. In: Higgins, A.K. \& Kalsbeek, F. (eds): East Greenland Caledonides: stratigraphy, structure and geochronology. Geological Survey of Denmark and Greenland Bulletin 6, 5-28 (this volume).

Sønderholm, M. \& Tirsgaard, H. 1993: Lithostratigraphic framework of the Upper Proterozoic Eleonore Bay Supergroup of East and North-East Greenland. Bulletin Grønlands Geologiske Undersøgelse 167, 38 pp.

Soper, N.J. 1994: Neoproteroic sedimentation on the NE margin of Laurentia and the opening of Iapetus. Geological Magazine 131, 291-299.

Steiger, R.H., Hansen, B.T., Schuler, C., Bär, M.T. \& Henriksen, N. 1979: Polyorogenic nature of the southern Caledonian fold belt in East Greenland. Journal of Geology 87, 475-495.

Stouge, S., Boyce, W.D., Christiansen, J., Harper, D.A.T. \& Knight, I. 2002: Lower-Middle Ordovician stratigraphy of North-East Greenland. Geology of Greenland Survey Bulletin 191, 117125.

Strachan, R.A., Nutman, A.P. \& Friderichsen, J.D. 1995: SHRIMP $\mathrm{U}-\mathrm{Pb}$ geochronology and metamorphic history of the Smallefjord sequence, NE Greenland Caledonides. Journal of the Geological Society (London) 152, 779-784.

Swett, K. \& Smit, D.E. 1972: Cambro-Ordovician shelf sedimentation of western Newfoundland, northwest Scotland and central East Greenland. Proceedings of the 24th International Geological Congress, Canada, 1972 6, 33-41.
Thrane, K. 2002: Relationships between Archaean and Palaeoproterozoic crystalline basement complexes in the southern part of the East Greenland Caledonides: an ion microprobe study. Precambrian Research 113, 19-42.

Vogt, P. 1965: Zur Geologie von Südwest-Hinks Land (Ostgrönland, $\left.71^{\circ} 30^{\prime} \mathrm{N}\right)$. Meddelelser om Grønland 154(5), 24 pp.

Watt, G.R. \& Thrane, K. 2001: Early Neoproterozoic events in East Greenland. Precambrian Research 110, 165-184.

Watt, G.R., Kinny, P.D. \& Friderichsen, J.D. 2000: U-Pb geochronology of Neoproterozoic and Caledonian tectonothermal events in the East Greenland Caledonides. Journal of the Geological Society (London) 157, 1031-1048.

Wegmann, C.E. 1935: Preliminary report on the Caledonian orogeny in Christian X's Land (North-East Greenland). Meddelelser om Grønland 103(3), 59 pp.

Wenk, E. 1961: On the crystalline basement and the basal part of the pre-Cambrian Eleonore Bay Group in the southwestern part of Scoresby Sund. Meddelelser om Grønland 168(1), 54 pp.

Wenk, E. \& Haller, J. 1953: Geological explorations in the Petermann Bjerg region, western part of Frænkels Land, East Greenland. Meddelelser om Grønland 111(3), 48 pp.

White, A.P., Hodges, K.V., Martin, M.W. \& Andresen, A. 2002; Geological constraints on middle-crustal behavior during broadly synorogenic extension in the central East Greenland Caledonides. International Journal of Earth Sciences 91, 187208.

Wordie, J.M. 1930: Cambridge East Greenland Expedition 1929: ascent of Petermann Peak. Geographical Journal 75, 481495 . 